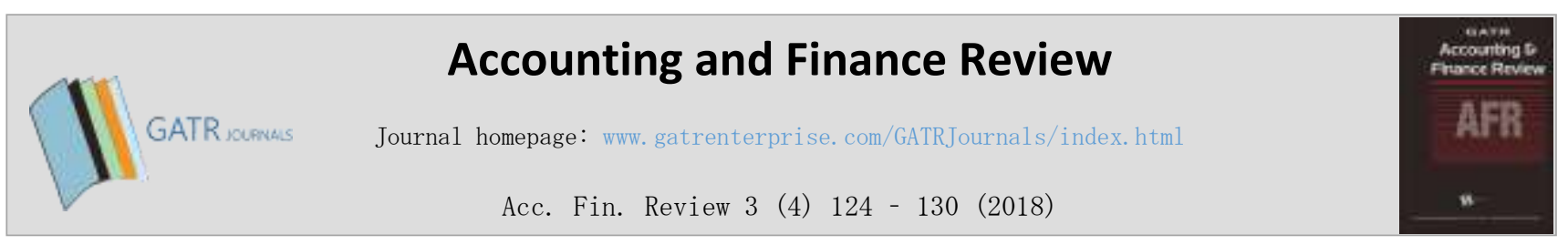

\title{
Gender-Diversity, Financial Performance and Cash Holding in Family Firms
}

\author{
Salehudin Eka Saputra Alrasidi, ST, ${ }^{1}$ Farida Titik Kristanti, S. E. M. Si ${ }^{2}$ \\ ${ }^{1,2}$ Telkom University, Faculty of Economics \& Business, 40153, Bandung, Indonesia
}

\begin{abstract}
Objective - This research aims to determine the presence of partial effects on gender-diversity and financial performance variables on the cash holding of family firms on the Indonesian Stock Exchange included in the Kompas100 index.

Methodology/Technique - The approach used in this research was causal associative testing using a panel data regression with a General Least Square (GLS) method using six independent variables: size, growth opportunity, dividend, return on assets, leverage, and gender diversity. Meanwhile, cash holding acts as a dependent variable.

Findings - The results of the research show that the independent variables of leverage have significantly negative relationships on cash holding on the Kompas100 index of Indonesia in the period of 2013-2016. Contrary to this, return on asset has a significantly positive relationship with cash holding.

Novelty - Gender diversity is an important variable of boardroom; this paper reveals the impact of gender diversity and performance on family holding firms. These results can be used to assess the performance and fundamentals of a firm.

Type of Paper: Empirical.
\end{abstract}

Keywords: Cash Holding; Dividend; Gender Diversity; Growth Opportunity; Leverage; Return on Assets; Size.

JEL Classification: M40, M41, M49.

\section{Introduction}

In 2014, a survey conducted by Price Waterhouse Cooper (PwC) on businesses in Indonesia showed that more than $95 \%$ of firms in Indonesia are family firms. According to Andres (2008), a firm can be classified as a family-owned business if its founder is a family member with at least $25 \%$ ownership through capital investment, or at least one family member of the founder occupies a position in the management of the firm. The Kompas 100 index in this research contains more than $60 \%$ of family firms.

* Paper info: Revised: October 30, 2018

Accepted: December 10, 2018

* Corresponding author: Salehudin Eka Saputra Alrasidi

E-mail: salehudin.eka@gmail.com

Affiliation: Faculty of Economics \& Business, Telkom University, Indonesia 
Between $70 \%-80 \%$ of the market capitalization on the Indonesian Stock Exchange is represented by 100 firms incorporated in the Kompas100 Index. Some previous research on cash holding have been conducted both nationally in Indonesia and internationally. Research conducted by Ajanthan, Alagathurai and Udhaya Kumara, KGA (2017) examines the effect of variables such as size, sales growth, net profit, board size, and gender diversity toward cash holding. On the other hand, Suherman (2017) examines the effect of firm size, leverage, board size, dividend payment, current ratio, sales growth, and gender diversity on cash holding. Meanwhile, Wasiuzzaman (2014) examines the effect of growth opportunities, net working capital, size, leverage, cash flow, capex, dividend, and board size variables. In addition, Gill and Shah (2012) examine the effect of net working capital, dividend payment, size, cash flow, and leverage. Moreover, a study conducted by Ogundipe and Salawu (2012) on the determinants of cash holding shows a negative and significant effect on firm size, net working capital, returns on asset, and bank relationships, and a positive impact on leverage, inventory, growth opportunities, financial difficulties and credit.

Based on previous research, some uncertainty remains on the effect of independent variables toward cash holding. This research examines the effect of size, leverage, dividend, growth opportunity, return on assets of financial performance, and gender-diversity of female board directors toward cash holding in family firms.

This study aims to determine the influence of cash holding in family firms based on gender-diversity and other independent variables, such as size, growth opportunity, dividend, leverage, and return on assets. The results of this study are expected to support the development of financial management science, especially on the topic of cash management, more specifically, cash holding.

\section{Literature Review}

Cash holding is a ratio used to compare the amount of cash along with the cash equivalent that belongs to a firm and the total assets of the firm. Cash holding is defined as the available or existing cash in the firm used to invest in assets or investments and used to be shared with investors (Gill \& Shah, 2012).

According to Keynes (1998), there are several benefits of cash holding for a firm: (1) a reduction in transaction costs, meaning it does not need to liquidate its assets to generate cash, (2) cash holdings will be helpful when the sources of financing outside of the cash are difficult to obtain or very expensive; and (3) having cash is a very useful source of finance.

Furthermore, there are several motives to holding cash. Keynes (1998) explains that there are at least three motives: (1) transaction motives which aim to provide cash to pay for various business transactions; (2) precautionary motives which aim to maintain cash balances to meet unexpected cash demands; and (3) speculative motives which aims to obtain benefit from owning or investing cash in the form of high liquidity investments.

Beside those cash holding motives, there are also some underlying cash holding theories including the Trade-off Theory, Pecking Order Theory, Agency Theory, and Free Cash Flow Theory. Trade-off Theory states that a firm defines its optimal level of cash holding, so that there is a balance between the benefits and costs arising from having the cash (Myers, 1984). Pecking Order Theory describes cash holding as a buffer between retained earnings and investment needs (Myers \& Majluf, 1984). Agency Theory explains the relationship among principals, agencies, and shareholders to encourage the distribution of money rather than cash investments in liquid assets (Jensen \& Mecking, 1976). Meanwhile, Free Cash Flow Theory states that problems will arise if a firm has a large cash ratio which results in limited capacity of external financing and less optimal investment (Jensen, 1986).

Andres (2008) states that firms are categorized as family firms if they meet one of two criteria. Firstly, the founders and/or family members of the founders must hold more than $25 \%$ of the voting rights, and secondly, the family members of the founders who hold less than $25 \%$ of the voting rights must hold specific positions within firm management. In Indonesia, the regulation regarding the ownership of a firm is stated in the directors decree of PT. Jakarta Stock Exchange No. Kep-305/BEJ/07-2004, which explains that a shareholder 
can be referred to as a controlling shareholder if the person owns $25 \%$ or more of the company's shares. Family Ownership reflects the firm's shares owned by the family. This indicates that, the greater the family ownership, the higher the control of the family on the firm.

\section{Research Methodology}

Based on the background and design of the study, this research is a causal associative research searching for causal relationships among independent variables or affecting variables $(\mathrm{X})$ and dependent variable or affected variable (Y). In this study, the dependent variable is cash holding, and the independent variables include firm size (SIZ), growth opportunity (PER), leverage (DAR), dividend payment (DPR), return on assets (ROA), and gender diversity (GD). Purposive sampling was used with specific criteria: the subjects must be family firms and they must possess complete data for the period between 2013 and 2016. Of the firm population listed on the Kompas 100 Index, 43 samples were identified.

The dependent variable (Y) in this study was cash holding, which refers to the money owned by a firm that is stored in petty cash or cash registers, or in the form of accounts both at bank and in the money market. Meanwhile, the independent variables of this research include gender diversity, firm size, growth opportunity, dividend payment ratio, leverage, and return on assets. Gender diversity is defined as the proportion of women on a board of directors within a firm (Harris et al. 2010). Firm size is the size of a firm which is measured using the natural logarithm of total assets (Gill \& Shah, 2012). Growth opportunity demonstrates the extent of a company's earnings per share which increases as debt increases (Brigham \& Houston, 2001). Dividend payments indicates the percentage of each profit obtained by the company which is distributed to the owner in cash. Dividend pay-out ratio is a ratio calculated based on the comparison between dividends per share and earnings per share (Gitman \& Zutter 2015). Leverage is a ratio that uses debt as a numerator on assets as its denominators (Rajan \& Zingales, 1995). Return on Asset measures the level of income from the total number of assets after interest and tax expenses (Brigham \& Houston, 2001).

The data analysis technique used in this study is panel data regression analysis. Panel data can be defined as a data set in which the behavior of a cross-section unit (company) is observed over a specific period.

There were several tests conducted in this study include descriptive statistics tests and the classical assumption test on multicollinearity and heteroscedasticity to estimate the model parameters with panel data. There are three techniques (models) that are often used: Common Effect, Fixed Effect, and Random Effect Models. The technique of the panel data estimation which was used to choose between the Fixed Effect and Common Effect models was the Chow test. Meanwhile, the Hausman test was performed to choose a model between the Fixed Effect and Random Effect models, and the Langrange Multiplier Test was used to choose a model between the Common Effect and Random Effect model. In this study, the hypothesis testing was carried out through two types of tests on the regression coefficients: $t$ - Test, which was used to test the regression coefficients individually, and the F-Test, which was used to test the coefficient hypothesis (slope) of the regression simultaneously.

\section{Results}

The results of the statistical description are shown in Table 1 which describes that on average, family firms listed on the Kompas 100 index have a relatively low cash holding, with a mean of 10.3919. Gender diversity also shows that the mean number is still relatively small. This means that the number of women on the board of directors is still relatively small. Family firms listed in the Kompas100 index also maintain a conservative capital structure because they have an average leverage of less than 50\%. Generally, firms have positive profits, so that they are able to pay their dividends. 
Table 1. Result of Descriptive Statistics

\begin{tabular}{|l|l|l|l|l|l|}
\hline Variable & $\mathrm{N}$ & Minimum & Maximum & Mean & $\begin{array}{l}\text { Std. } \\
\text { Deviation }\end{array}$ \\
\hline CH & 172 & 0.250 & 32.684 & 10.39 & 7.444 \\
\hline SIZ & 172 & 14.72 & 20.332 & 16.83 & 1.100 \\
\hline PER & 172 & -35.52 & 299.33 & 22.83 & 31.814 \\
\hline DPR & 172 & -31.34 & 683.00 & 32.29 & 61.001 \\
\hline ROA & 172 & -64.38 & 71.50 & 7.804 & 10.717 \\
\hline DAR & 172 & 0.010 & 1.90 & 0.4956 & 0.243 \\
\hline GD & 172 & 0.000 & 66.66 & 15.907 & 16.786 \\
\hline
\end{tabular}

A heteroscedasticity test which was conducted using a Park test which shows that all of the independent variables have a probability level above the significant level of 5\%. Therefore, it can be said that heteroscedasticity is not present in the research data. The multicollinearity test indicates that the test results of all of the independent variables show a tolerance values of $>0.10$ and a VIF values of $<10$. This means that this research data is considered to have no multicollinearity.

Based on the estimation technique, the regression models with panel data can be estimated using three estimation methods: the Common Effect model, the Fixed Effect model, and the Random Effect model. Meanwhile, the selection of the right model can be achieved using the Chow test, the Hausman test, and the Langrage test.

Table 2. Results of the Determination of the Estimation Model

\begin{tabular}{lrrll}
\hline \hline Uji & Statistic & Prob. & Hasil \\
\hline \hline Uji Chow & 17.566142 & 0.0000 & $\mathrm{H}_{0}$ ditolak dan $\mathrm{H}_{1}$ diterima & Fixed Effect \\
Uji Hausman & 6.161030 & 0.4054 & $\mathrm{H}_{0}$ diterima & Random Effect \\
\hline \hline
\end{tabular}

Based on the results of the Chow and Hausman test models, the Lagrange Test was not conducted because the results of both the Chow and Hausman tests prove that the Random Effect model is better suited compared to the Common Effect model and Fixed Effect model.

The F-tests show that the value of Prob (F-statistic) is 0.0000, which is smaller than the Alpha value of 0.05. Consequently, $\mathrm{H} 1$ is accepted, meaning that the simultaneous effect of the independent variables toward the dependent variable is proven to be statistically significant. The coefficient of determination (Goodness of Fit) is denoted by R-squares, which reflects how many variations of the dependent variable can be explained by the independent variables. The results of data processing in this study show that the value of the Determination Coefficient (R2) is 0.192235 , which means that a set of predictor variables in the model can explain only $19 \%$ of the variability in the response. Meanwhile, the remaining $81 \%$ is explained by other variables not included in the model.

The t-test results show that only ROA and DAR have a significant influence on the cash holding of family firms in Indonesia, particularly those listed on the Kompas100 Index. Meanwhile, other variables, such as firm size (SIZ), dividend (DPR), growth opportunity (PER), and gender diversity (GD) have no significant influence on cash holding because the probability level is greater than the significance level which is $10 \%$. 
Table 3. T-Test Results

\begin{tabular}{crrcl}
\hline \hline Variabel & Coefficient & Prob. & Result & Conclution \\
\hline \hline C & 4.095968 & 0.0114 & & - \\
SIZ & -0.101516 & 0.2803 & $\mathrm{H}_{0}$ rejected & Not Significant \\
DPR & 0.000523 & 0.3829 & $\mathrm{H}_{0}$ rejected & Not Significant \\
ROA & 0.018869 & 0.0178 & $\mathrm{H}_{0}$ accepted & Significant *** \\
DAR & -1.080935 & 0.0001 & $\mathrm{H}_{0}$ accepted & Significant $* * *$ \\
PER & -0.032244 & 0.7631 & $\mathrm{H}_{0}$ rejected & Not Significant \\
GD & 0.071444 & 0.8549 & $\mathrm{H}_{0}$ rejected & Not Significant \\
\hline \hline
\end{tabular}

Note: Significance Level $*=10 \%, * *=5 \%, * * *=1 \%$

\section{Discussion}

Return on Assets (ROA) has a significantly positive effect on the cash holding at a significance level of $5 \%$, which is 0.0178 , with a regression constant value of 0.018869 . The results of this study illustrate that the greater the level of cash holding in a firm, the more equipped the firm will be able to manage its assets to generate profits. A greater level of cash holding ratio allows firms to avoid high external costs in financing and providing flexibility to exploit profitable investment opportunities. These results are consistent with research by Ogundipe et al. (2012). However, the findings are in contrast to research by Bigelli and Vidal (2009) and Afza and Adnan (2007), who conclude that return on assets has a negative effect on cash holding.

Leverage represented by Debt to Asset Ratio (DAR) has a significantly negative effects on cash holding with a significant level of $1 \%$ and a value of 0.0001 , and a regression constant of -1.080935 . The results of this study describe that a greater level of cash holding ratio allow firms to avoid high external costs of financing. This also provides flexibility for firms to exploit profitable investment opportunities. Unlike equity financing, debt requires debt payments or interest payments. Thus, debt can be far more expensive than equity financing. A higher cash holding will result in a greater amount of assets that can be used by firms to generate operating incomes, which will reduce the firm's debt ratio. A decline in the debt asset ratio usually implies a more financially stable business. These results are consistent with research by Subramaniam, Tang and Zhou (2011), Afza and Adnan (2007), Kusnadi (2007), Luo and Hachiya (2005) and Ozkan and Ozkan (2004). However, the results are inconsistent with the findings of Ogundipe et al. (2012) and Gill and Shah (2012).

\section{Conclusion}

For any firm, maintaining an optimal cash holding ratio allows the firm to have a cash inventory which can be used to fulfil its transaction, precautionary and speculative motives in order to be able to exploit profitable investment opportunities. The results of this study show that there are significantly partial effects between return on asset and cash holding leverage. A higher cash holding value of a company may refer to a higher level of flexibility of the assets owned by the firm which can be used to foster firm growth in generating profits. It also results in a higher ratio of return on assets. Debt to asset ratio is a predictor of the firm's ability to meet its long-term obligations. Hence, the higher the level of cash holding of a company is, the less the firm relies on debt. Moreover, this encourages the firm to reduce its dependence on external financing/debt.

Firms must pay attention to the indicators of financial performance as the main barometer to determine the company's performance, such as return on assets and leverage, which have a significant level of partial influence on cash holding. The higher the cash holding of a company is, the more efficient the assets owned by the company will be. This can produce optimal profits and provide the ability to fulfil long-term obligations to reduce the company's level of debt. On the other hand, investors who invest their capital can 
observe the indicators of return on assets and leverage to assess whether a firm is healthy or not. Good financial performance and optimal stock value will attract investors.

Further research should include further independent variables, as the independent variables examined in this study are only able to predict $19 \%$ of the variation in the dependent variable. Further, the use of different regression techniques should be considered to acknowledge and determine the significant relationships between the variables observed. The scope of the study may also be expanded by examining a number of samples or by extending the study period.

\section{References}

Ajanthan, Alagathurai and Udhaya Kumara, KGA. (2017). Corporate Governance and Cash Holdings: Empirical Evidence from an Emerging Country, Sri Lanka. International Journal of Accounting and Financial Reporting ISSN 2162-3082 2017, 7(2).

Andres, C. (2008). Large Shareholders and Firm Performance: An Empirical Examination of Founding-family Ownership. Journal of Corporate Finance, 14(4), 431-445.

Cambrea, Domenico, Ponomareva, Yuliya and Pittino, Daniel. (2018). Cash Holdings and Firm Value: The Moderating Roles of Family Involvement and Board Structure. Academy of Management Proceedings. 2018. 14684. 10.5465.

Filip Fidanoski, Kiril Simeonovski, Vesna Mateska. (2014), The Impact of Board Diversity on Corporate Performance: New Evidence from Southeast Europe, Emerald Group Publishing Limited, 17, 81-123.

Gill. A dan Shah, C. (2012). Determinants of Corporate Cash Holdings: Evidence from Canada. International Journal of Economics and Finance. 4(1). www.ccsenet.org/ijef.

Gitman, Lawrence J., dan Chad J. Zutter. 2015. Principles of Managerial Finance. Fourteenth Edition. Pearson.

Gizelle Willows, Megan van der Linde, (2016) Women Representation on Boards: A South African Perspective, Meditari Accountancy Research, 24(2), 211-225.

Gujarati, D. N. and Porter, D. C. (2009) Basic Econometrics. 5th Edition, McGraw Hill Inc., New York.

Harris, N. D., Broome, L., Hamlin, D., Jordan, A. C. and Lee, D. C. (2010). SEC Disclosure Rules on Board of Director Diversity. In American Bar Association Annual Meeting, San Francisco, CA.

Jensen, M. C dan Meckling, W.H. 1976. Theory of the Firm: Managerial Behaviour, Agency Costs and Ownership Structure. Journal of Financial Economics, 3(4), 305-360.

Keynes, J. M. (1936), The General Theory of Employment, Interest and Money, Macmillan, London.

Kuan, T. H., Li, C. S. dan Chu, S. H. (2012), Corporate Governance and Cash Holdings: A Quantile Regression Approach, International Review of Economics and Finance, 24, 303-314.

Kusnadi, Y. (2007), Corporate Cash Holdings, Board Structure and Ownership Concentration: Evidence From Singapore, Working Paper, Hong Kong University of Science and Technology, Hong Kong, October.

Luo, Q. and Hachiya, T. (2005), Corporate Governance, Cash Holdings and Firm Value: Evidence from Japan, Review of Pacific Basin Financial Markets and Policies, 8(4), 613-636.

Myers, Stewart C., Majluf, Nicholas S. (1984). Corporate Financing and Investment Decisions When Firms Have Information That Investors Do Not Have. Journal of Financial Economics. 13(2), 187-221.

Ogundipe, Lawrencia Olatunde, Sunday Ogundipe, dan Samuel Ajao (2012). Cash Holding and Firm Characteristics: Evidence from Nigerian Emerging Market. Journal of Business, Economics and Finance, 1(2), 45-58.

Opler, T., Pinkowitz, L., Stulz, R. and Williamson, R. (1999), The Determinants and Implications of Corporate Cash Holdings, Journal of Financial Economics, 52(1), 3-46

Ozkan, A. and Ozkan, N. (2004), Corporate Cash Holdings: An Empirical Investigation of UK Companies, Journal of Banking and Finance, 28(9), 2103-2134.

Pastor, Corina Camelia, and Paulo M Gama. (2013), Determinant Factors of Cash Holdings: Evidence from Portuguese SMEs, International Journal of Business and Management, 8(1).

Rajan, R. G., \& Zingales, L. (1995). What do we know about capital structure? Some evidence from international data. The journal of Finance, 50(5), 1421-1460.

Sciascia, S., \& Mazzola, P. (2008). Family involvement in ownership and management: Exploring nonlinear effects on performance. Family Business Review, 21(4), 331-345.

Sheikh, Nadeem Ahmed. and Wang, Zongjun. (2011), Determinants of corporate cash holdings: A case study of Pakistan, Managerial Finance Emerald Insight, Vol. 37 Issue: 2, pp.117-133. 
Subramaniam, V., Tang, T. T., Yue, H., \& Zhou, X. (2011). Firm structure and corporate cash holdings. Journal of Corporate Finance, 17(3), 759-773.

Suherman, S. Effect of Women's CEO on the Company's Cash Holding. MIX: Management Scientific Journal, 7 (1). 